$\begin{array}{ll}\text { Research Square } & \begin{array}{l}\text { Preprints are preliminary reports that have not undergone peer review. } \\ \text { They should not be considered conclusive, used to inform clinical practice, } \\ \text { or referenced by the media as validated information. }\end{array}\end{array}$

\title{
Impact of Library Activities on Labour Market Outcome
}

Abbos Utkirov ( $\square$ autkirov@gmail.com )

Westminster International University in Tashkent https://orcid.org/0000-0002-1926-7384

Rauf Salahodjayev

Westminster International University in Tashkent

\section{Research}

Keywords: Alumni, Employability, Human resource development, Labour market, Library activities

Posted Date: October 18th, 2021

DOl: https://doi.org/10.21203/rs.3.rs-957534/v1

License: () (7) This work is licensed under a Creative Commons Attribution 4.0 International License. Read Full License 


\section{Abstract}

Purpose

This paper investigates the impact of the Learning Resource Centre activities of Westminster International University Tashkent (WIUT) graduated students on the labour market outcome. WIUT library provides a learning environment that helps students create functional teams and individual projects to support employability. The study aims to clarify the relationship between library activities and labour market outcomes. It proposes an employability guide to improve a commercial responsiveness workshop in collaboration with other services and alumni voices.

Design/methodology/approach

A quantitative research approach was employed; an online survey questionnaire was distributed to alumni students to obtain the data. It was a semistructured questionnaire designed using a Likert Scale to collect data from 607 graduates.

Findings

The study revealed that LRC activities have a significant impact on labour market outcomes for students. LRC activities such as presentation skills, information technology skills, problem-solving skills, research skills were expected mainly by the labour market.

Research limitations

The study was focused only on graduates of WIUT, which may limit the generalizability. Therefore, the researcher proposed to study and compare other graduates of universities in Uzbekistan.

Practical implications

The insights are valuable for planning the curriculum of LRC activities and developing teaching practices at WIUT. Moreover, current and graduate students can learn market-oriented skills and labour market demands.

Originality/value

This is the first-ever study in Uzbekistan that explores the relationship of university library activities on the employability skills of alumni.

\section{Introduction}

In order to endure relevancy, libraries have been acclimating their services to meet the new requirements, demand for materials, and services (Goulding, 2006; Hunt, 2017; Jerrard, 2009). For instance, public libraries have been increasing the number of curriculums and offered resources. Employability of students and skills is an essential priority for the sector of Higher Education. WIUT offers support for developing employability, and this will be common across other institutions. The University has been developing and updating a new vision for information and digital literacy (IDL) activities. Workshops, research activities, and project collaboration at LRC WIUT can create an environment that will benefit students to adapt and become familiar with the real working environment when they approach the real-life practical workplace. More explicitly, the development of IDL workshops through a time of student at University will position them well for the level of graduate and employment and will fill them with life skills that can be transferred to the requirements of the progressively complex digital world (Mawson \& Haworth, 2018).

There is proof to appear that abilities are measured exceedingly noteworthy by graduated employers. A report by Universities UK (2016, pp. 30-31) recommends that there is coherence exists among graduates and managers, and esteemed aptitudes/skills and working experience are considered as a vital factor in achieving business success (Mawson and Haworth, 2018; Finch et al., 2013). Availability of a learning environment of subscribed databases, project and teamwork facilities, and IDL workshops will enhance achieving higher grades and provide the atmosphere of the working process of real life. As a Brown et al. (2015, pp. 4-5) highlight, "terms such as 'entrepreneurial skills', 'problem-solving, and 'team working' might be translated in different by instruction suppliers, businesses and occupations" Exploration of problem statements could be articulated as whether there is a relationship between university library activities on employability skills of graduated students of WIUT. Therefore, identifying required current labor market skills and basing on them designing a curriculum of LRC activities can create 'skills translation', which assists how and why these soft skills can be applied. Organizing guest lectures with real successful managers, supervisors of the different organizations at the Learning resource center assists students to become more familiar with combining the theoretical approaches with real practical life experiences.

The following section reviews the extant literature of variances among workplaces and academia. It may lead to challenges and opportunities in promoting LRC activities such as guest lectures, reading clubs, embedded sessions, information, digital literacy training, group, individual, and the team works as employability attributes. The research highlights the benefits of LRC activities and collaboration with students, and effective services beyond the library in the employability arena.

\section{Literature Review}

There is extensive international literature on alumni perceptions about library activities and employability and an insignificant number in Uzbekistan. Some research has concentrated on the extent and importance of the labor market by exploring opportunities for employment in Library and Information Science (LIS). Other studies are more dedicated to the knowledge and mix of preferred skills or those required by the employers of the labor market (Genoni and Smith, 
2005; Warraich and Ameen, 2010; Anne Kennan et al., 2006; Raju, 2004; Aina and Moahi, 1999; Varalakshmi, 2006; Croneis and Henderson, 2002; Stilwell, 2004; Lutwama and Kigongo-Bukenya 2004; Stephens and Hamblin, 2006; Ocholla and Shongwe, 2013).

Genoni and Smith (2005) investigated a study of LIS graduate job achievement outcomes in the prospects of Australia. It was a longitudinal study conducted by Curtin University of Technology graduates. The study population was alumni students who completed their studies from 1988-1992, 1993-1997, and 19982002. The study of 1998-2002 was compared with the outcomes of the past two studies. The outcomes indicated that many graduates searched for jobs related to the information outside libraries, and the supply of employment from Curtin University is few comparing with previous years. Moreover, the use of the library was limited, and international students experienced challenges due to a lack of familiarity. The findings support the need to develop library professionals' awareness of international students' use of library facilities.

Warraich and Ameen (2011) discovered a gap in the perception of alumni students about the library science curriculum's relevance to the labor market needs of Pakistan. The research was conducted with separate questionnaires for both targeted groups using the five-point Likert scale from 1 to 5 . In general, alumni students and employers were satisfied with the products of DLIS and recommended them as able to enhance the employability of new specialists through social and soft skills and others.

Kennan et al. (2006) measured a change in employers' needs related to information professionals in Australia. The change was observed in 135 advertisements for four weeks in $2004,1994,1984$, and 1974 . Their study exposed the change of job patterns. In 1974, requests were inviting technicians or references, while in 2004, the most required attributes were behavioral characteristics and interpersonal skills.

Raju (2004) and Stilwell (2004) both piloted research from the perspective of South Africa and evaluated the awareness of employers and graduates on the appropriateness of the program to the LIS working atmosphere. Raju (2004) conducted comparative research on the curricula of LIS and the needs of employers, concluding that LIS postgrad diploma programs are reputable in South Africa. Another study carried out by Stilwell (2004) at Natal University revealed that LIS curricula achieved the predicted outcomes in postgraduates' preparation.

The research was conducted by Aina and Moahi (1999) and Lutwama and Kigongo-Bukenya (2004) on the appropriateness of the East Africa School of Library and Information Science (EASLIS) from 1995 to 1999 in Uganda and Botswana University, respectively. Both studies revealed that, from the employers' perspective, the graduates of EASLIS lacked practical skills. Aina and Moahi (1999) demonstrated the dissatisfaction of current library-related jobs by respondents because of lower socioeconomic class. These skills gaps needed to be filled with Information Literacy (IL) courses.

Varalakshmi (2006) carried out comparative research on the employability of LIS alumni and the curricula of LIS at the University of Andhra in India. The survey was conducted among graduates and library professionals; it evaluated the advertisements of employees to identify the views and expectations of target groups regarding develop employment opportunities. However, LIS professionals were not satisfied with the outcomes of library institutions and believed that teaching technology, management, and soft skills to students would produce the competitiveness of employability in the future (Fajaryati et al., 2020).

Croneis and Henderson's (2002) study was from an American perspective using advertisements from College and Research Libraries News over 11 years (1990-2001). They revealed an increasing quantity of electronic and digital positions, and the current demand was more on supervisory and administrative job responsibilities. Their findings demonstrated the rapid change of the scale and nature of professions due to emerging technology.

(2018) states that libraries should promote physical and monetary resources to attract users and promote the programs that the labor market requires. Participation of students on library programs may not help to find jobs, nevertheless it can reduce the cost which may be needed to join on the labor market. Activities are concentrated on skill training and job services. Program can help not only finding jobs but keeping the jobs for adults and positively effect on participation of labor force and impact negatively on unemployment of young generation (Hunt, 2017).

\section{Objectives Of The Study}

Identification of research gaps and emerging research questions led to determine the following key objectives:

- Obtain the key competencies of LRC curriculum development

- Identify the factors of LRC activities that can benefit labor market outcomes

- Determine their Library strategies for employability successes

Moreover, WIUT library is one of the best-equipped libraries and provides a learning environment and activities which can suit the relevant labor market needed skills for students in Uzbekistan. Therefore, there is a demand to determine the employability skills of alumni students.

\section{Research Design}

Quantitative methods were employed during the research. A descriptive quantitative research design was applied to establish an association between the variables. As part of quantitative methods, a survey questionnaire was distributed to alumni students in the online google form. The research was based on this survey questionnaire. It was a semi-structured questionnaire designed using a Likert Scale to collect data. The questionnaire was designed to gather alumni students' experiences.

4.1 Data collection

Page 3/18 
The primary data was gathered in the online google form questionnaire from January to April 2020 among ( $N=607$ ) alumni graduates (See Appendix, Figure A1). The Career Centre of WIUT provided access to alumni students' contact details. The questionnaire consisted of four parts and had a combination of open and closed questions. The questionnaire incorporated questions on:

- personal information

- opinions about the curriculum learning while studying at WIUT

- perception of employability skills

- use of the library

The questionnaire's standard indicator data sets were adopted from Warraich (2008). Moreover, secondary data were obtained from databases, journal articles, and books. In order to determine the participation in LRC activities, the 1024 WIUT alumni graduates were given the online questionnaire, and 607 of them responded (See Appendix, Figure A1). Quantitative data analysis was used to discover the differences in employability and position between high attended alumni and low attended alumni on LRC activities and workshops.

\section{The Data Analysis And Interpretation}

\subsection{Profile of respondents}

Malhotra (2010) highlights that the core objective of data analysis is to obtain valuable insights through research questions. Online google form survey (See Appendix, Figure A1) was sent to graduate students via e-mail, cell phone (messaging), telegram (messenger), Facebook, and Linkedln. 110 (18\%) graduates responded to the questionnaire via e-mail, 72 (12\%) via Facebook, 37 (6\%) via Linkedln, 74 (12\%) via cell phones and messaging, and 314 via Telegram (WIUT Alumni Network, 2020). Software for Statistics and Data Science (Stata) and the Tableau data visualization analysis tool were used to analyze and manage the quantitative data. Graduates who were on maternity leave and continued their masters studies were about 63 respondents, and they were excluded to eliminate the subjectivity of library activities' impact on employability.

The demographic profile is described next. 607 students out of 1024 participated in this survey. The response rate was nearly $60 \%$. 391 (64.3\%) respondents were male, and $217(35.7 \%)$ were female 371 (61\%) of the respondents were working in private sectors while 173 (29.7\%) were in public sectors. 63 (10\%) alumni were on maternity leave or continuing their studies. 504 (83\%) of the respondents were aged between $21-30$. The remaining 103 (17\%) of the respondents were over $30(31-42)$.

The salary of 239 (39\%) graduates was above 6000000 Uzbek soum, while 305 (50\%) was from less than 2000000 to 6000000 Uzbek soum per month. 63 (105) of the whole $(\mathrm{N}=607)$ respondents were on maternity leave and studying. It should be noted that the 471 (77\%) students who frequently visited libraries (from once a day or month) have a salary of over 5 million soum compared to the $73(12 \%)$ students who visited rarely and never ( $\mathrm{N}=544)$, excluding maternity leave and studying students (63 respondents).

Figure 1 demonstrates that married graduates earn more, from $4 \mathrm{mln}$ (Uzbek soum) to above six mln (Uzbek soum), while the single professionals' proportion is among less than two $\mathrm{mln}$ (Uzbek soum) to $3 \mathrm{mln}$ (Uzbek soum). It means that married people are more responsible and keen on earning more money. Another point is that married people can be more experienced and have the opportunity to find high-salary jobs (Figure 7).

As Figure 2 shows, male students were visited more compared to female respondents. The highest percentage ratio of 9 percent of daily visits on the female while 24 percent of male visits were observed 2-3 times a week. It means that male students were more dedicated to participating in LRC activities compared to females.

Most of the respondents $(300,62 \%)$ got their first job within one month of graduation - 271 of these respondents (90.3\% out of 300) were students who frequently visited libraries. 196 (37\%) respondents got their first job within 4-6 months. The remaining $6 \%$ got their job in the range of 7 to 24 months (Figure 3). It should be noted that 63 respondents' answers were maternity and studying reasons, and 19 of respondents' answers were blank or error. Therefore, their responses were excluded from providing an accurate analysis. As stated above, 62 percent of students who frequently visited libraries got their job during the first month. This demonstrates the excellent labor market for WIUT graduates in Uzbekistan.

In order to discover the intensity of the relationship between the variables, following the correlation matrix can help to illustrate an accurate outcome.

\section{Correlation matrix}

According to the results from this correlation matrix, in the line of library visits, it can be observed that the highest absolute correlation exists between income (salary) of respondents and frequency of library visits with a nearly moderate positive relationship ( $r=.4$ ). As research questions 1 and 2 identify the positive effects of LRC activities on students' employability, it is helpful to note the statistically significant correlation ( $90 \%$ confidence) between income and how frequently the students visited the library. Additionally, a negative correlation was observed between library visits and gender ( $r=-.01)$ and library visits and employee category $(r=-0.10)$

\section{Table 1: Correlation Matrix}




\begin{tabular}{|c|c|c|c|c|c|c|c|c|}
\hline & Library Visits & Income (salary) & Age & Gender & Working Sector & Marriage & Employee category & Faculty \\
\hline Library Visits & 1.00 & & & & & & & \\
\hline Income (salary) & $0.40 *$ & 1.0000 & & & & & & \\
\hline Age & $0.13^{*}$ & $0.37 *$ & 1.00 & & & & & \\
\hline Gender & -0.01 & $-0.21 *$ & $-0.12^{\star}$ & 1.00 & & & & \\
\hline Working Sector & $0.13^{*}$ & 0.02 & 0.021 & 0.02 & 1.00 & & & \\
\hline Marriage & $0.13^{*}$ & $0.28^{*}$ & $0.54^{\star}$ & -0.06 & 0.05 & 1.00 & & \\
\hline Employee category & $-0.10^{\star}$ & $-0.24^{*}$ & -0.07 & $0.12^{\star}$ & -0.02 & -0.06 & 1.00 & \\
\hline Faculty & 0.02 & 0.03 & 0.07 & 0.01 & $0.14^{\star}$ & -0.04 & -0.05 & 1.00 \\
\hline
\end{tabular}

A strong correlation can be observed (income line) between age and income, meaning a person earns more money as he or she is grown, which is statistically significant ( $r=.37)$. There is a relatively positive correlation between income and faculty $(r=.03)$ and income and the working sector $(r=.02)$, but they are not statistically significant. We can observe the highest statistically significant correlation in this table between age and marriage ( $r=.54$ ), which means more older people are married than young people. For gender, the highest score of a statistically significant relationship can be observed between gender and employee category $(r=.12)$. For the working sector, the highest is only between the working sector and faculty ( $r=.04)$. The faculty and employee category has a relatively negative correlation ( $r=.05)$ which means it does not matter which category of employment suits the student (part-time, permanent, or other) as the degree type (business, economics, IT, others.) does not affect.

A scatterplot can show us a more detailed visual. As we see, only Postgraduate students of WIUT have a visible increase in the scale of income as the graduates become older and show a positive statistically significant correlation in all aspects (Figure 4).

Figure 5 shows that as a person becomes aged, they earn more money. It alludes to becoming more experienced and competent, providing further opportunities for earning a higher income.

If breakdown into two sectors as Figure 6 illustrates that graduates who started to work in public sectors are younger and the faster the increase in income compared to private sector employees. Moreover, from Figure 7, we can observe that married people earn more compared to single people.

As we can see in the summary of regression output, several points can be noted in Table 2. The number of observations is 544 . It should be noted that 63 respondents $(607-63=544)$ were excluded because of maternity and studying reasons to provide accurate calculations. F-Test shows that the p-value is .000, which means the results are highly significant; the significance level is $95-99 \%$ percent, respectively. R-square (0.1633) is not equal to zero, which means the regression model has some explanatory power. R-squared is a statistical measure of how close the data are to the fitted regression line. As the R-Square value is between 0 and 1 and it is the coefficient of determination. It is closer to 1 and it is better as close to 0 means the worst the model. As Table 2 shows, 16.33 percent of variation shows a weaker relationship even that is statistically significant of library visits of student's effect on the income of respondents. However, the other 16 percent is either unexplained or an error in this model. Following from R-Squared, T-value can also be interpreted as less than 0.1 ; we can see that both coefficients in library visits are suitable, essentially the coefficient for library visits rate is equal to zero, and the constant is also equal to zero. It means that frequent library visits have a significant effect on the income of students after graduation. The coefficient for library visits is .46 and 2.50 for the constant. It essentially shows the nature of the relationships between variables. When income is zero, the library visits are 2.50 . As we see, .46 is a positive number which means frequent library visits have a positive relationship with the income of WIUT alumni students. Owing to this fact, it observes that one more student's visit to the library caused a 0.5 increase in income of students after graduation from university (Table 2).

Table 2: Regression analysis income (wage) to frequent visits to the library

\begin{tabular}{|c|c|c|c|c|c|c|}
\hline \multicolumn{3}{|c|}{ ANOVA (Analysis of variance) } & \multicolumn{4}{|c|}{ Regression statistics } \\
\hline \multirow[t]{2}{*}{ Source } & \multirow[t]{2}{*}{ SS } & \multirow[t]{2}{*}{ df } & \multirow[t]{2}{*}{ MS } & \multicolumn{2}{|c|}{ Number of obs $=$} & \multirow{2}{*}{$\begin{array}{l}544 \\
105.76\end{array}$} \\
\hline & & & & $F(1,542)$ & $=$ & \\
\hline \multirow[t]{4}{*}{ Model } & 235.775442 & 1 & 235.775442 & Prob $>\mathrm{F}$ & $=$ & 0.0000 \\
\hline & 1208.34221 & 542 & 2.22941366 & R-squared & $=$ & 0.1633 \\
\hline & \multirow[t]{2}{*}{1444.11765} & \multirow[t]{2}{*}{543} & \multirow[t]{2}{*}{2.65951685} & \multicolumn{2}{|c|}{ Adj R-squared = } & 0.1617 \\
\hline & & & & Root MSE & $=$ & 1.4931 \\
\hline \multicolumn{7}{|l|}{ Coefficients } \\
\hline Income & Coef. & Std. Err. & $\mathrm{t}$ & $P>t$ & [95\% Conf. & Interval] \\
\hline Library visits & .460076 & .0447379 & 10.28 & 0.000 & .3721951 & .547957 \\
\hline cons & 2.495247 & .2106269 & 11.85 & 0.000 & 2.081502 & 2.908992 \\
\hline
\end{tabular}

We can conclude that library activities have a significant impact on students' labor market outcomes. 
To see the significant difference between means of opinions, the Likert scale (Tableau data visualization analysis tool) has been used to measure (from 1 to 5) the most frequent responses, which is the mode and average score by working sector (Figure 8). As we can see in all aspects, alumni students who work in the public sector provided the opinion that WIUT Learning Resource Center (library) activities (training sessions, reading club, conferences, and events) play an influential role in developing the skills in all aspects compared to private sector employees. The highest scores in the private sector are research

(Avg.Score=3.98) and searching skills (Avg.Score=3.87), while public sector research (Avg.Score=4.31) and searching skills (Avg.Score=4.31) are leading with a higher score. The lowest score has different skills development as the private sector has information technology (Avg.Score=3.36) while in the public sector has practicality (Avg.Score=3.62) (Activities contents are related to Practical approach). It can be assumed that library activities' impact is lower in IT skills for the private sector, whereas practicality's impact is lower in public sectors. As WIUT has concentrated on a blended learning approach, library activities should develop IT and practical approaches in designing its curriculum.

Similar outcomes can be observed in that research skills lead in both married (Avg.Score=4.18) and single (Avg.Score=3.99) respondents. The lowest score with practicality in married (Avg.Score=3.63) and single (Avg.Score=3.34). It means that the married and the single score has no significant difference in all aspects.

When we compare the two categories, it can be observed that learning activities have lower scores in all aspects compared to employability skills. It indicates that students perceived most soft skills during their studies at WIUT as unimportant until they approached accurate employment procedures. Therefore, the importance of employability skills should be developed with a more practical approach in designing the curriculum of LRC activities. These outcomes and analysis from alumni students can help to produce more practical and current skills development for students to develop and maintain further employability opportunities. It suits the third research question. This study intends to attract beneficial LRC activities to students and design more developed curricula in upcoming academic years.

\section{Table 3: Average wage rate of WIUT students}

\begin{tabular}{llllll} 
Sum of income & & & & & \\
Variable & Obs & Mean & Std. Dev. & Min & Max \\
\hline Salary (income) & 544 & 4.558824 & 1.630803 & 1 & 6
\end{tabular}

Table 3 shows valuable information; the average salary wage is about 4.6 million Uzbek soum for 544 respondents.

Both the academic and administrative staff of WIUT university must become aware of the reasons students come to the university and the library. From Figure 15 , we can determine that students visit LRC to complete assignments (85\%), prepare for exams (76\%), research (55\%), borrow books (38\%), reference (37\%), and others. The results prove that most students come to the library to study to become successful in their careers and lives.

As we see, students mainly use circulation services (57\%) and book a reservation (48\%), which means that students mainly use the library to check out resources. However, the usage of referencing (42\%) and digital library $(32 \%)$ services demonstrates that the library is moving to a blended learning model. However, there are many essential services of WIUT LRC, such as referencing tool session (11\%), which teaches database usage and proper referencing. Nonetheless, not many students are aware of or do not intend to learn this, which is much needed in completing assignments and research purposes. Moreover, the WEB OPAC service (8\%) provides a service to manage reserved and borrowed books online at home. Therefore, these needed tools should be considered for further development by WIUT LRC services.

\section{Summary and recommendations}

As we see, the actual outcomes showed a significant effect of LRC activities on employability at all. It was interesting to see the difference between research outcomes in a different perception of graduate students from different perspectives, backgrounds, cultures, and others. Frequent library visits have a positive relationship with the income of WIUT alumni students. However, students need to improve presentation skills, IT skills, problem-solving, research skills, which are vital to enrich employability in the labor market. Since students are not aware of the labor market needs until they approach the actual workplace, the library specialists should collaborate with academic staff and practitioners to implement market-driven skills into curricula and transfer them to current students. Collaboration between academic and library staff can be related to choosing appropriate learning resources and enclosing information literacy skills in curricula. Such collaboration maintains the relevance of information instruction to particular disciplines and increases the students' perceived value (Pham \& Tanner, 2015). Thus, the learners will be aware of the current labor market needs and improve their competencies.

Moreover, enhancing internship opportunities and practical opportunities can help be aware of the essential skills required by potential employers. It should be noted that the study is limited to those who studied at WIUT. Comparing the research with other library activities of universities in Uzbekistan will help to create applicable curricula for activities that can provide valuable insights for future graduates' employability. Furthermore, the employment status and salary of graduates continuing their studies can not be measured because they may not work or work as part-time employers. Also, not every graduate of WIUT was reached to be answered for the questionnaire. Some alumni preferred not to fill the questionnaire because the salary-related question seemed confidential information for them even though it is anonymous.

Based on survey results, LRC professionals should design the curriculum materials in IT skills, presentation skills, problem-solving skills, and research skills. Training faculty librarians on web searching, design of databases, referencing tools should also be part of the program. Moreover, the designation of the course should be revised considering the employability market changes with a flexible approach every two or three years. Conducting longitudinal research 
can provide the opportunity of evaluating students and labor market needs. Working with the university's Career Center can help build and maintain networking among universities and employers.

\section{Conclusion}

Although this project is intended for a deep analysis of the impact of WIUT LRC activities on labor market outcome, limitations and recommendations were observed and listed above. Analysis of current research provided valuable information for WIUT university and the library to measure the impact of LRC activities in the employability arena. The world is changing quickly, and theoretical knowledge is becoming insufficient to survive in the competitive market. Activities should be concentrated on market-oriented skills to resolve the challenging employer needs. Also, it needs to enhance market-driven skills on LRC activities such as presentation skills, IT skills, problem-solving, research skills with high intensive motivation and commitment at the university. Furthermore, developing an innovative program to enhance soft skills for library staff can provide professional experts that can encourage labor market needed skills development for students' career and life success (Junrat et al., 2014). Implementing features that can strengthen the skills of the current job market and curriculum of LRC activities should mirror to produce talented professionals for the information marketplace.

\section{Abbreviations}

WIUT: Westminster International University in Tashkent; LRC: Learning Resource Centre; IDL: Information and Digital Literacy; LIS: Library and Information Science; EASLIS: East Africa School of Library and Information Science; IL: Information Literacy; IT: Information Technology

\section{Declarations}

\section{Acknowledgments}

We would like to thank and be grateful to Dr. Viktoriya Levinskaya, WIUT LRC Enhancement Unit, and WIUT Research department for their support in conducting questionnaires and the structure of this paper. Special thanks to WIUT Career Centre and Alumni Unit for providing access to alumni students.

\section{Authors' contributions}

All authors read and approved the fnal manuscript. Funding Not applicable. Availability of data and materials Not applicable.

\section{Funding}

Not Applicable

\section{Availability of data and materials}

Data available on request due to privacy/ethical restrictions

\section{Ethics approval and consent to participate}

The research undertook the ethical procedures and consent form provided to participants.

\section{Consent for publication}

Current paper has the consent for publication from all authors.

\section{Author details}

${ }^{1}$ Enhancement Unit, Westminster International University in Tashkent- An Accredited institution of the University of Westminster, London, UK, ${ }^{2}$ Senior Research Fellow, Westminster International University in Tashkent- An Accredited institution of the University of Westminster, London, UK

\section{Conflict of Interest Statement}

On behalf of all authors, the corresponding author states that there is no conflict of interest.

\section{References}

Aina, L, and Moahi, K. (1999). Tracer study of the Botswana library school graduates / Semantic Scholar. https://doi.org/https://doi.org/10.3233/EFI-199917304

Aina, L. O., \& Moahi, K. (1999). Tracer study of the Botswana library school graduates. Education for Information, 17(3), 215-244. https://doi.org/10.3233/EFI1999-17304

Brown, A. N., Rankin, K., Picon, M., \& Cameron, D. B. (2015). The state of evidence on the impact of transferable skills programming on youth in low-and middle-income countries. https://www.3ieimpact.org/sites/default/files/2019-01/sp4-youth_and_transferable_skills.pdf 
Croneis, K. S., \& Henderson, P. (2002). Electronic and digital librarian positions: A content analysis of announcements from 1990 through 2000. Journal of Academic Librarianship, 28(4), 232-237. https://doi.org/10.1016/S0099-1333(02)00287-2

Fajaryati, N., Budiyono, B., Akhyar, M., \& Wiranto, W. (2020). The employability skills needed to face the demands of work in the future: Systematic literature reviews. Open Engineering, 10(1), 595-603. https://doi.org/10.1515/eng-2020-0072

Ferreira Neto, B., Market Paper Amir Borges Ferreira Neto, J., Boudreaux, C., Conaway, B., Deskins, J., Freguglia, R., Grossman, D., Fernandes, I., Humphreys, B., Jackson, R., Lin, J., Matti, J., Marioni, L., Minuci, E., Nowak, A., Pyun, H., Ross, A., Ross, J., Sayago, J., ... Zhou, Y. (2018). Do public libraries impact local labor markets? Evidence from Appalachia Do Public Libraries Impact Local Labor Markets? Evidence from Appalachia I would like to thank Izabella. https://mpra.ub.uni-muenchen.de/89584/1/MPRA_paper_89584.pdf

Finch, D. J., Hamilton, L. K., Baldwin, R., \& Zehner, M. (2013). An exploratory study of factors affecting undergraduate employability. Education And Training, 55(7). https://doi.org/10.1108/ET-07-2012-0077

Genoni, P., \& Smith, K. (2005). Graduate employment outcomes for qualifying library and records management courses at curtin university of technology, 1998-2002. Australian Library Journal, 54(4), 336-352. https://doi.org/10.1080/00049670.2005.10721782

Goulding Anne. (2006). Public Libraries in the 21st Century. E-Conversion - Proposal for a Cluster of Excellence; Routledge. https://doi.org/10.4324/9781315602912

Hunt, K. (2017). Library Programs and Services for New Adults. Libraries Unlimited. https://books.google.co.uz/books? id=YE83DwAAQBAJ\&pg=PA92\&lpg=PA92\&dq=Library+Programs+and+Services+for+New+Adults+Kyla+Hunt+pdf\&source=bl\&ots=sQGuoaKvm\&sig=ACfU3U07N3B6ZUJjDm6tRhkzKZKiOVuwXw\&hl=ru\&sa=X\&ved=2ahUKEwiG18Wu5-DtAhUii8MKHRmzCr84ChDoATAEegQIBRA

Jerrard, J. (2009). Crisis in Employment: A Librarian's Guide to Helping Job Seekers. American Library Association. https://books.google.co.uz/books? $\mathrm{id}=$ AePSfMFsVTMC\&pg=PA44\&lpg=PA44\&dq=Jerrard,+J.+Crisis+in+employment+a+librarian\%27s+guide+to+helping+job+seekers + +American+Library+Associ

Junrat, S., Jenphop, C., Suravee, R., \& Kanokorn, S. (2014). Soft Skills for University Library Staff in Thailand. Procedia - Social and Behavioral Sciences, 112, 1027-1032. https://doi.org/10.1016/j.sbspro.2014.01.1265

Kennan, M. A., Cole, F., Willard, P., Wilson, C., \& Marion, L. (2006). Changing workplace demands: What job ads tell us. In Aslib Proceedings: New Information Perspectives (Vol. 58, Issue 3, pp. 179-196). Emerald Group Publishing Limited. https://doi.org/10.1108/00012530610677228

Lutwama, E. and Kigongo-Bukenya, I. M. N. (2004). A tracer study of the East African School of Libraryand Information Science graduates 1995-1999 working in Uganda / Lutwama / South African Journal of Libraries and Information Science. https://doi.org/https://doi.org/10.7553/70-2-675

Malhotra, N. (2010). Marketing Research: An Applied Orientation (S. Yagan (ed.); 6th ed.). Prentice Hall. http://www.ru.ac.bd/wpcontent/uploads/sites/25/2019/03/407_08_00_Malhotra-Marketing-Research-An-Applied-Orientation.pdf

Mawson, M., \& Haworth, A. C. (2018). Supporting the employability agenda in university libraries. Information and Learning Science, 119(1/2). https://doi.org/10.1108/ILS-04-2017-0027

Ocholla, D., \& Shongwe, M. (2013). An analysis of the library and information science (LIS) job market in South Africa. South African Journal of Libraries and Information Science, 79(1). https://doi.org/10.7553/79-1-113

Pham, H. T., \& Tanner, K. (2015). Collaboration Between Academics and Library Staff: A Structurationist Perspective. Australian Academic and Research Libraries, 46(1), 2-18. https://doi.org/10.1080/00048623.2014.989661

Raju, J. (2004a). First level i library and/or information science education and training at South African universities and technikons: developments in specialisation. https://doi.org/https://doi.org/10.7553/70-1-689

Raju, J. (2004b). First level library and/or information science qualifications at South African universities and technikons: a comparative study of curricula. South African Journal of Libraries and Information Science, 70(1). https://doi.org/10.7553/70-1-689

Stephens, D., \& Hamblin, Y. (2006). Employability skills: Are UK LIM departments meeting employment needs? The results of a survey of employment agencies identifies gaps in UK LIM curricula in the UK. New Library World, 107(5-6), 218-227. https://doi.org/10.1108/03074800610665211

Stilwell, C. (2004). Alumni perceptions of a post graduate Information and LibraryScience Education programme at the University of Natal, South Africa. South African Journal of Libraries and Information Science, 7O(1). https://doi.org/10.7553/70-1-691

Universities UK. (2016). Higher education in England: provision, skills and graduates. https://dera.ioe.ac.uk/27441/1/higher-education-in-england-provisionskills-and-graduates.pdf

Varalakshmi, R. S. R. (2006). Educating 21st Century LIS Professionals-Needs and Expectations: A Survey of Indian LIS Professionals and Alumni. Journal of Education for Library and Information Science, 47(3), 181. https://doi.org/10.2307/40323829 
Warraich, N., \& Ameen, K. (2011). Alumni Perception of Library and Information Science Programme and Graduate Employment Outcomes at the University of the Punjab. November.

Warraich, N. F. (2008). LIS Graduates Employability-Needs and Expectations of the Library and Information Science (LIS) curriculum at the University of the Punjab (PU): An appraisal of Pakistani LIS Professionals Date: 02/07/2008. Education And Training, 2007, 1-20.

Warraich, N. F., \& Ameen, K. (2010). Employment and learning outcomes of LIS graduates: A case of Pakistan. Education for Information, 28(2-4), 315-324. https://doi.org/10.3233/EFI-2010-0914

\section{Figures}

\section{Average monthly salary breakdown by marital status (in Uzbek soums)}

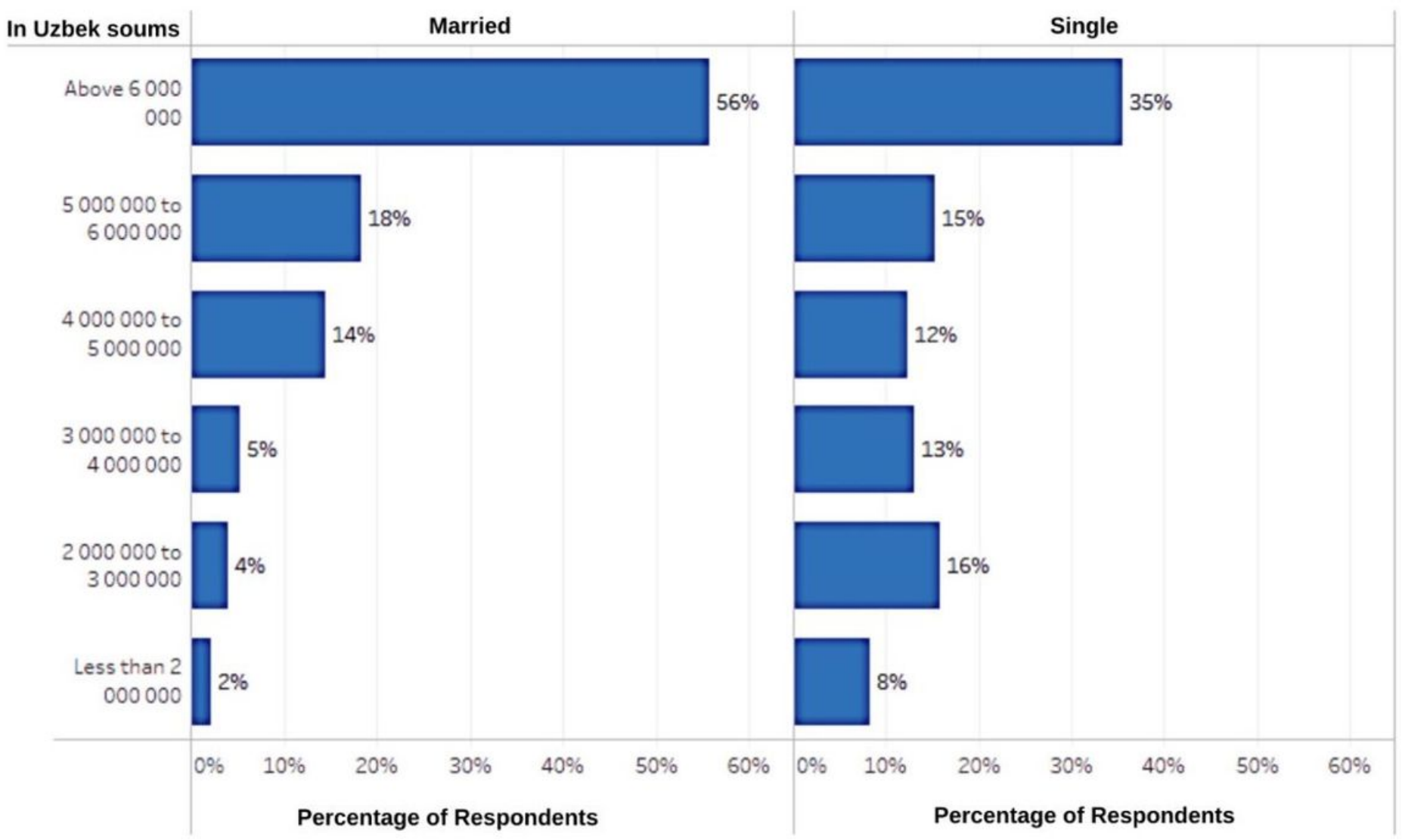

Figure 1

Average monthly salary breakdown by marital status (in Uzbek soums) 


\section{Frequency of library visits by gender (Out of 607)}

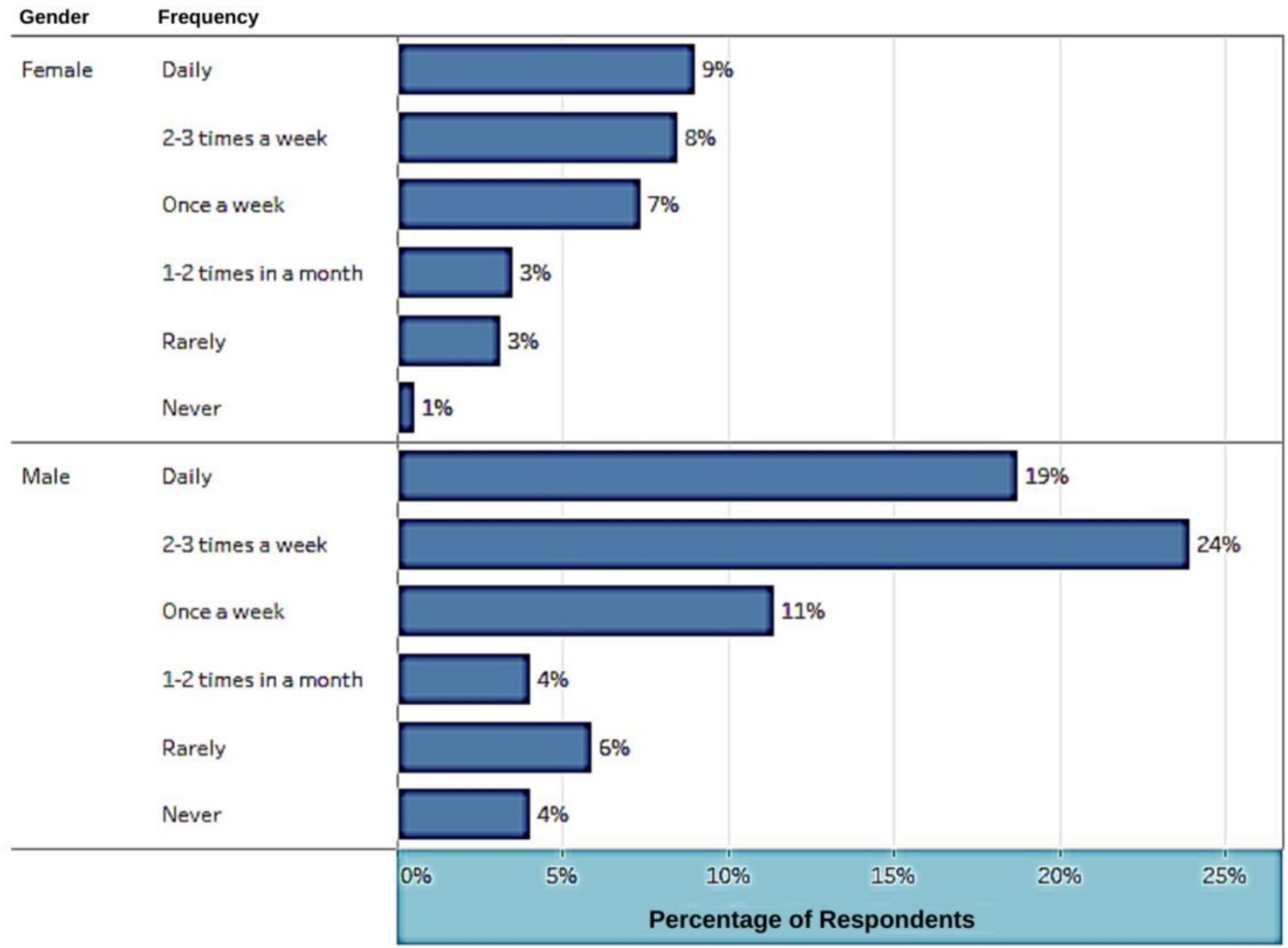

Figure 2

Frequency of library visits by gender (Out of 607) 


\section{Unemployment period after graduation (Out of 525)}

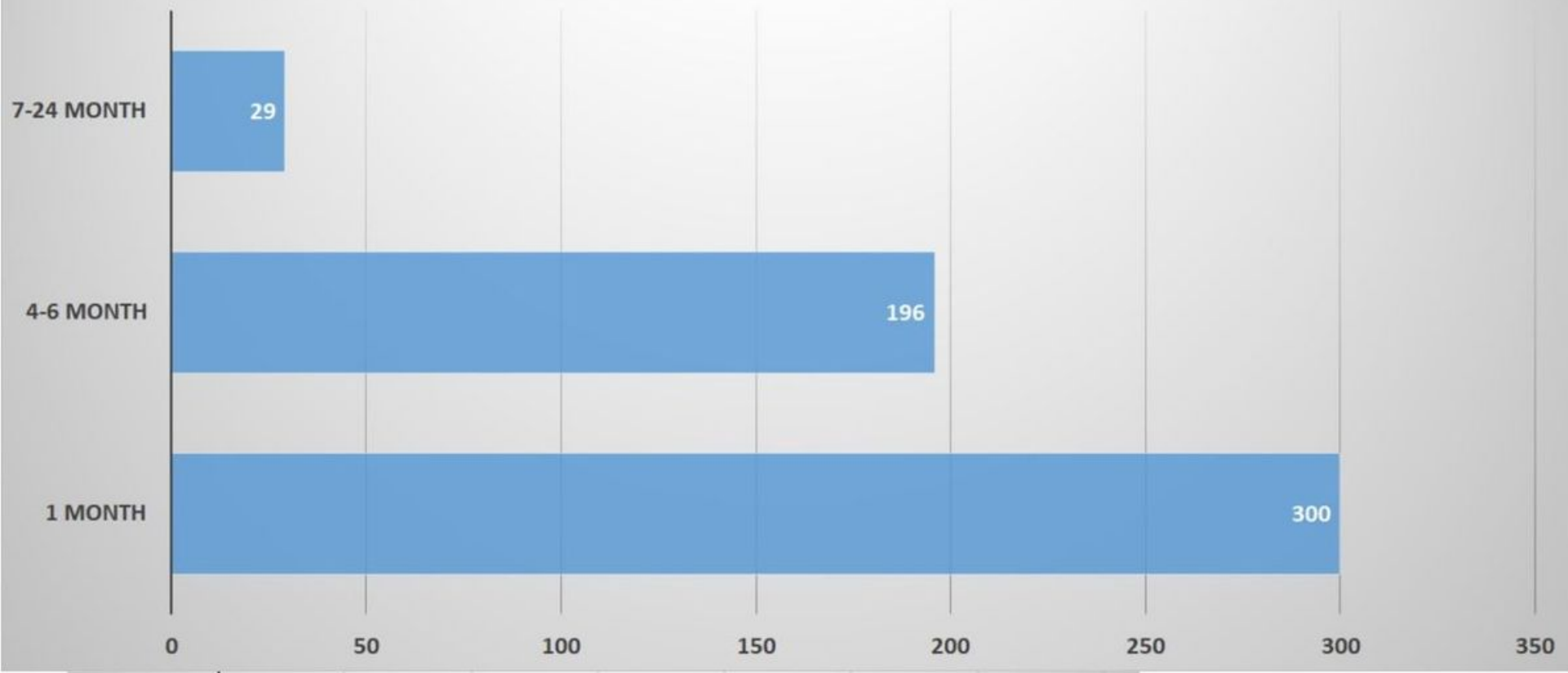

Figure 3

Unemployment period after graduation (Out of 525)

Scatterplot by age and income broken down by faculty

Faculty breakdown

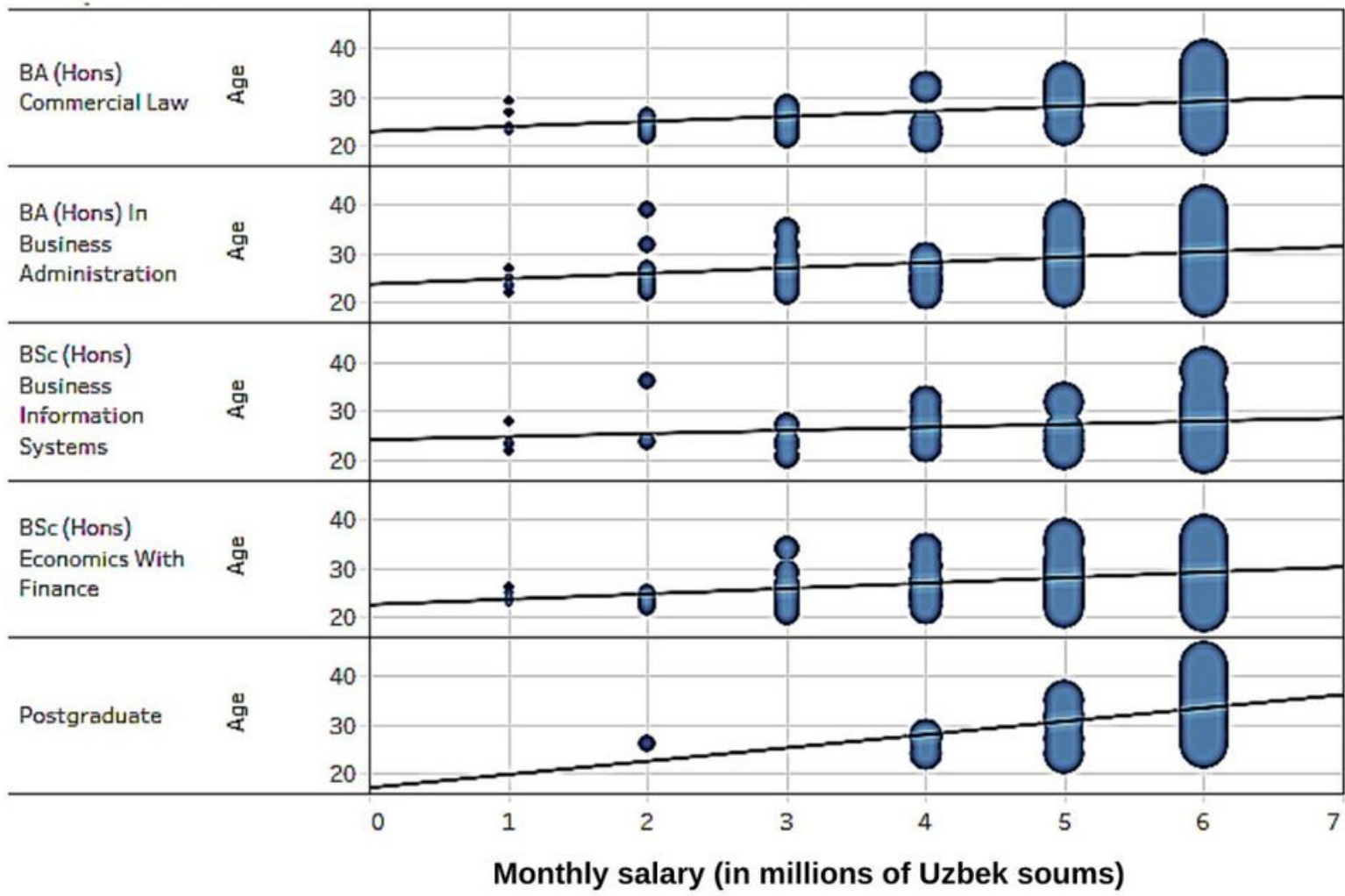

Salary range

- Less than 2000000 O2000000 to 30000 .

O3000 000 to 40000 .

C 4000000 to 50000 .

5000000 to 60000 .

Above 6000000 


\section{Correlation Matrix of income (salary) and age}

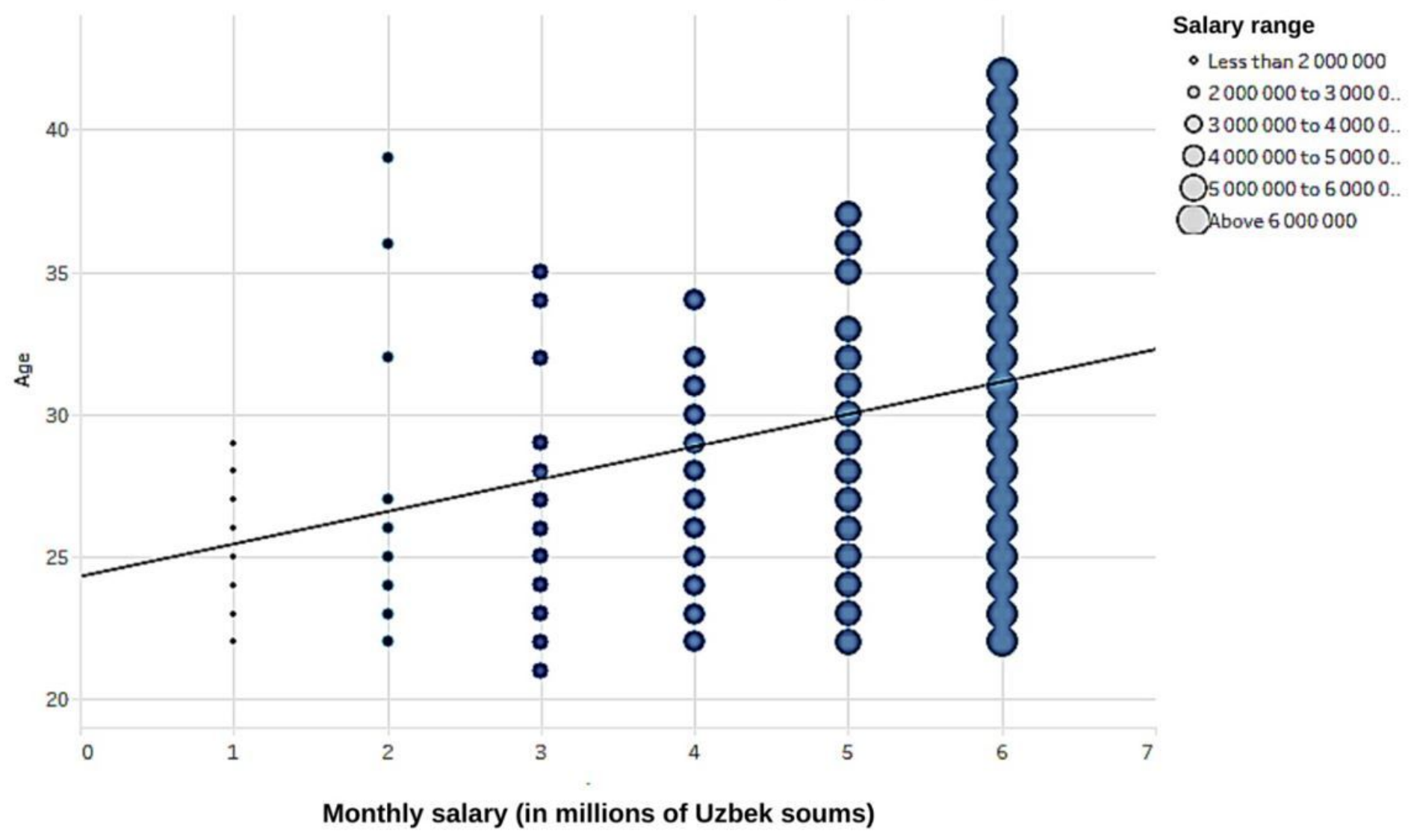

Figure 5

Correlation Matrix of income (salary) and age 
Scatterplot by age and income (salary) broken down by sectors

Sector

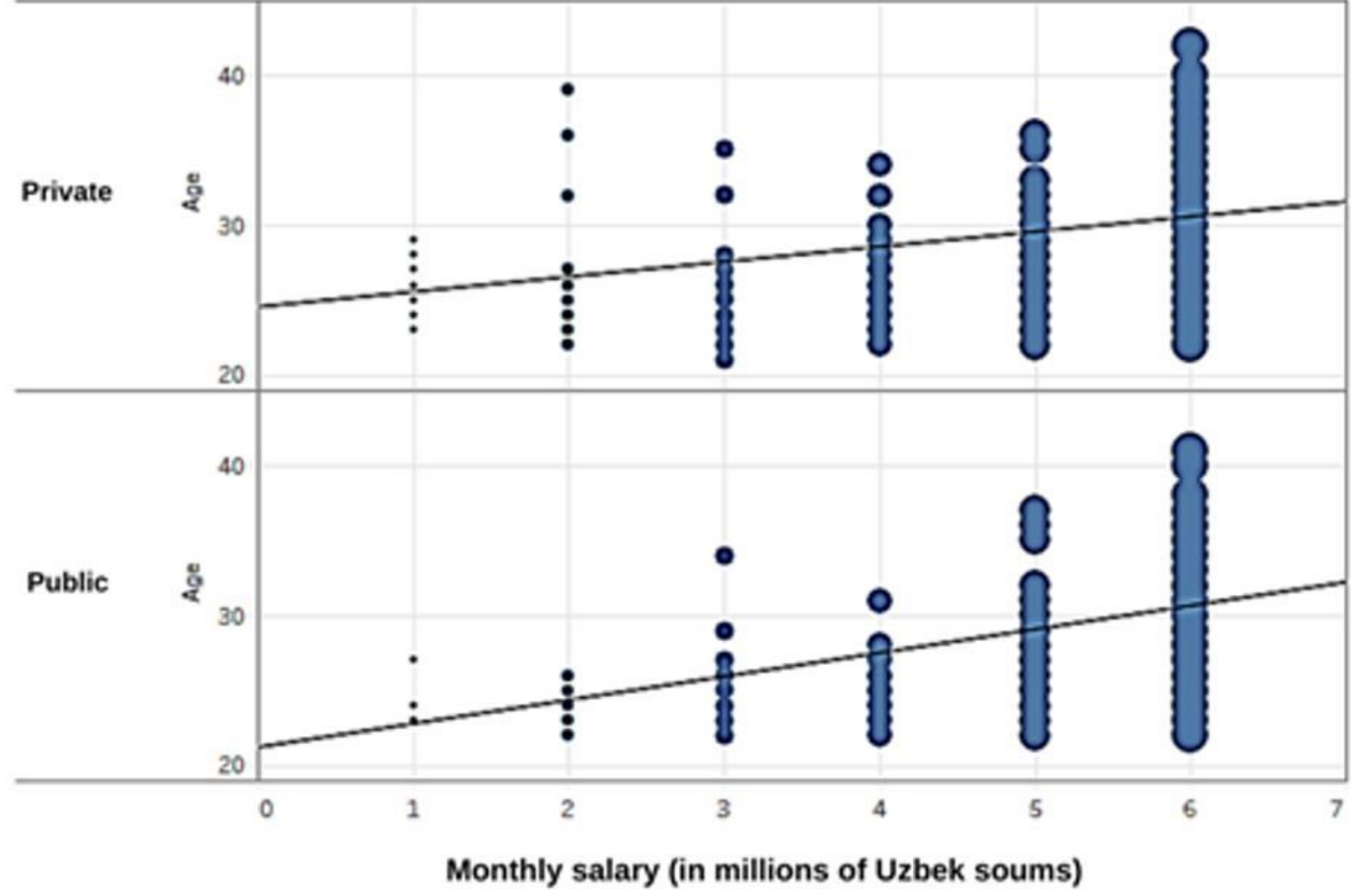

Salary range

- Less than 2000000

- 2000000 to 30000 .

O 3000000 to 40000 .

O4000000 to 50000 .

S 5000000 to 60000 .

()above 6000000

Figure 6

Scatterplot by age and income (salary) broken down by sectors 
Scatterplot by age and income (salary) broken down by marital status

Marital status

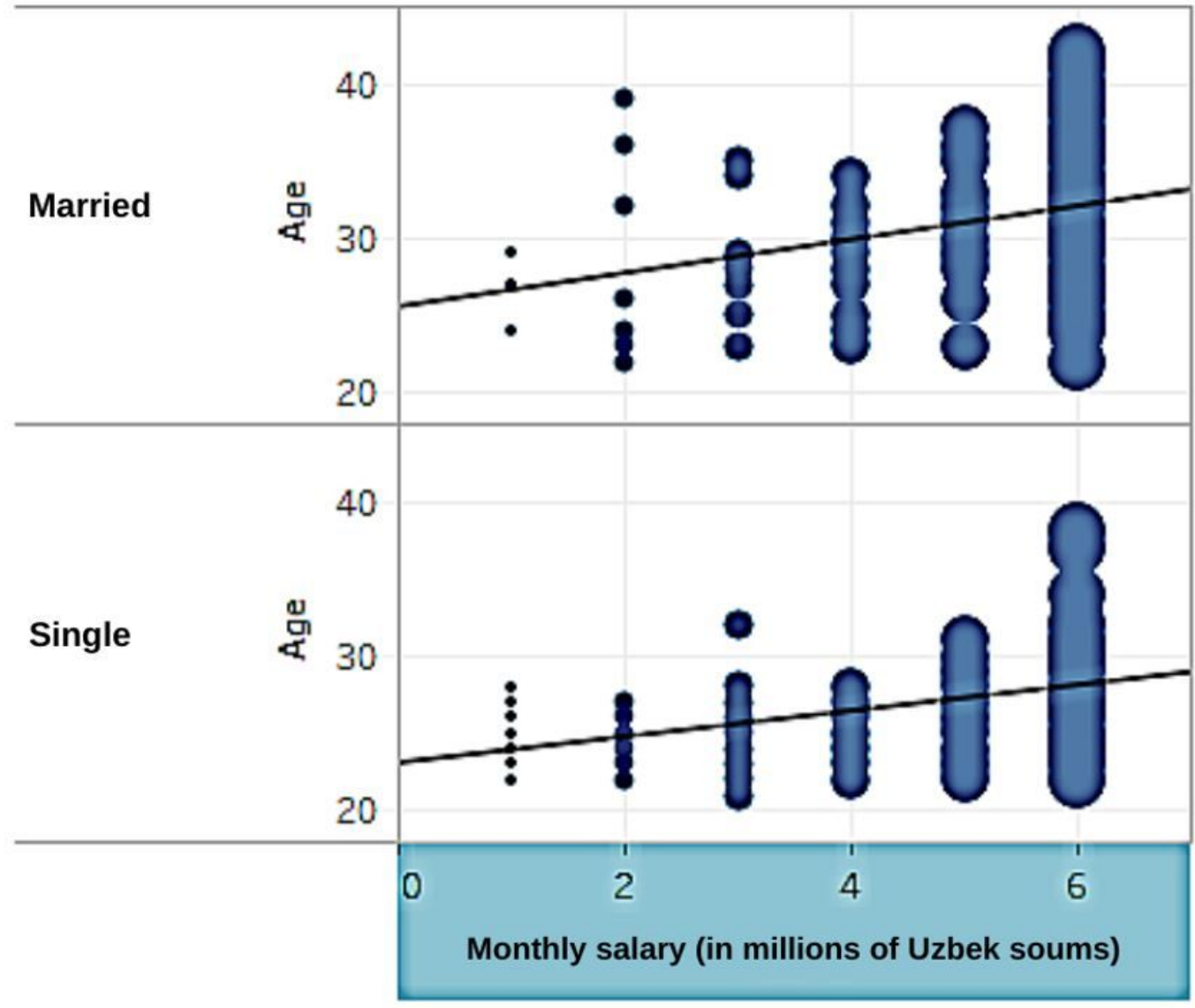

Salary range

- Less than 2000000

- 2000000 to 30000 ..

O 3000000 to 40000 ..

O4000000 to 50000 ..

5000000 to 60000 ..

Above 6000000

Figure 7

Scatterplot by age and income (salary) broken down by marital status 


\section{Graduates opinion about library activities at WIUT:}

Average score between private and public sector

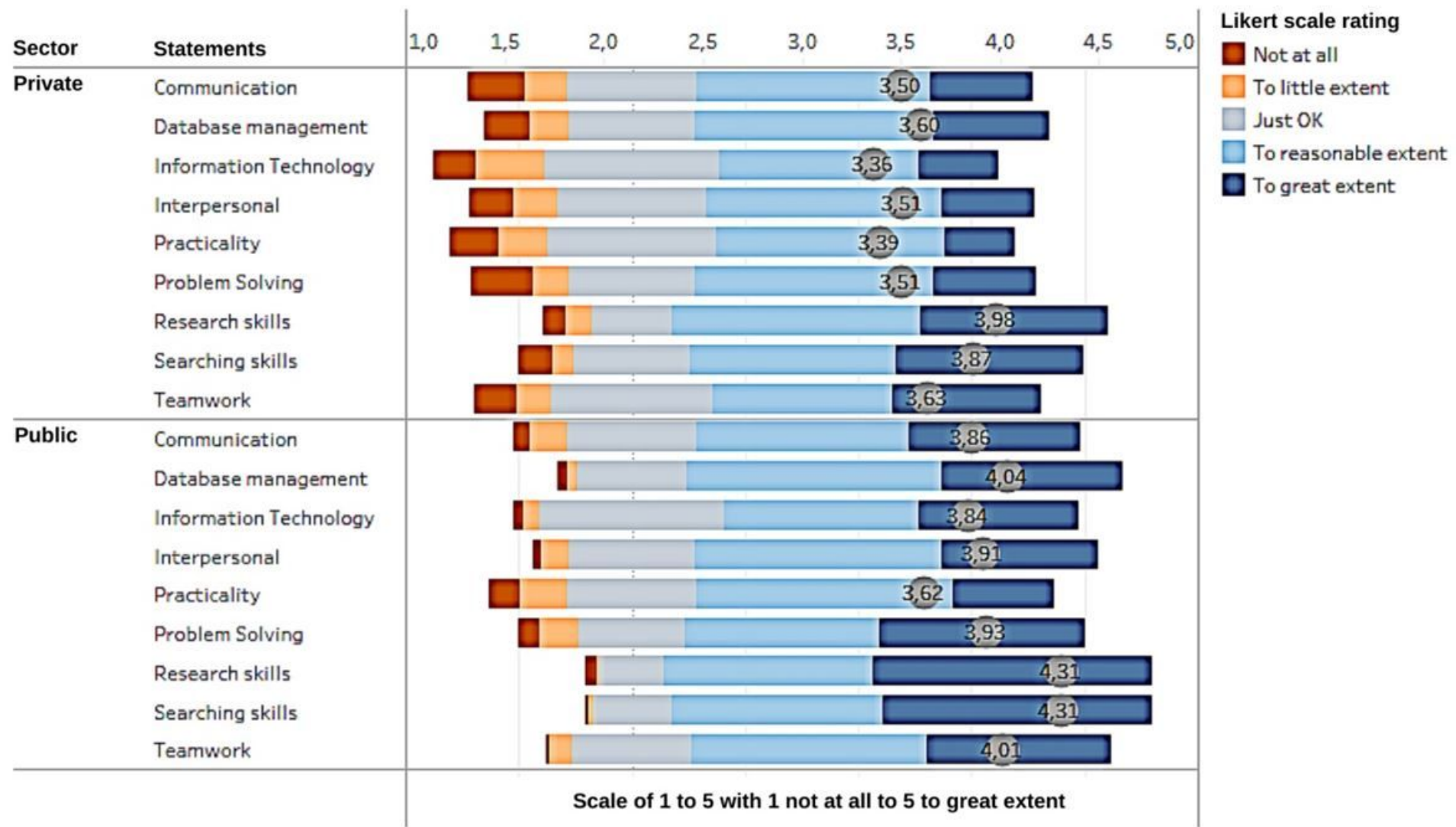

Note: 1- Not at all 2-To a little extent 3-Just OK 4-To reasonable extent 5-To great extent

Figure 8

Graduates opinion about library activities at WIUT: 


\section{Graduates opinion about library activities at WIUT: \\ Average score between married and single}

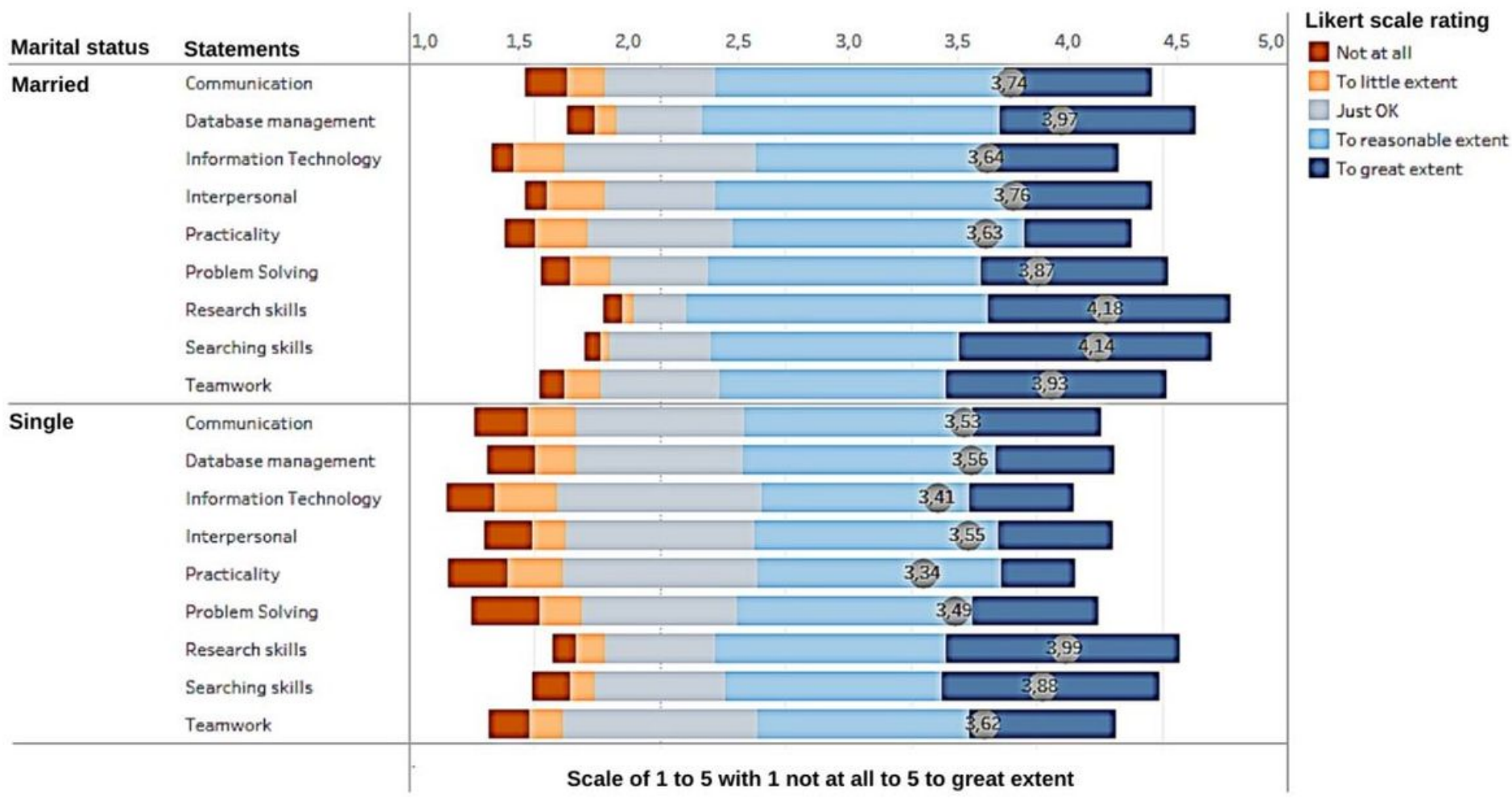

Note: 1- Not at all 2-To a little extent 3-Just OK 4-To reasonable extent 5-To great extent

Figure 9

Graduates opinion about library activities at WIUT 


\section{Average score between learning activities and perception of employability skills}

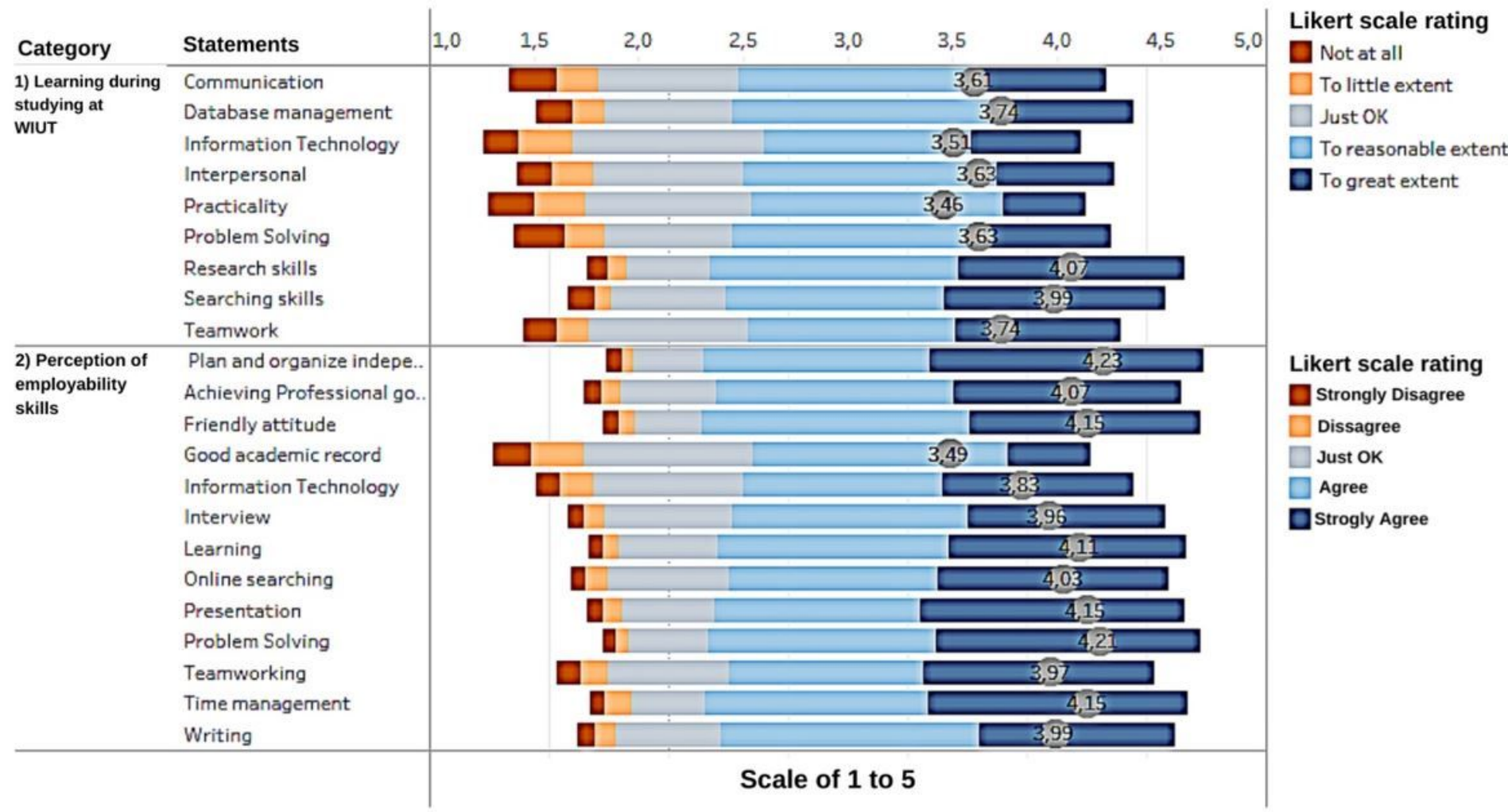

Notes: Category 1: 1-Not at all 2-To a little extent 3-Just OK 4-To reasonable extent 5-To great extent Category 2: 1-Strongly Disagree 2-Disagree 3-Just OK 4-Agree 5-Strongly Agree

Figure 10

Average score between learning activities and perception of employability skills

\section{Purpose of students' visiting WIUT library during studies (Out of 607)}

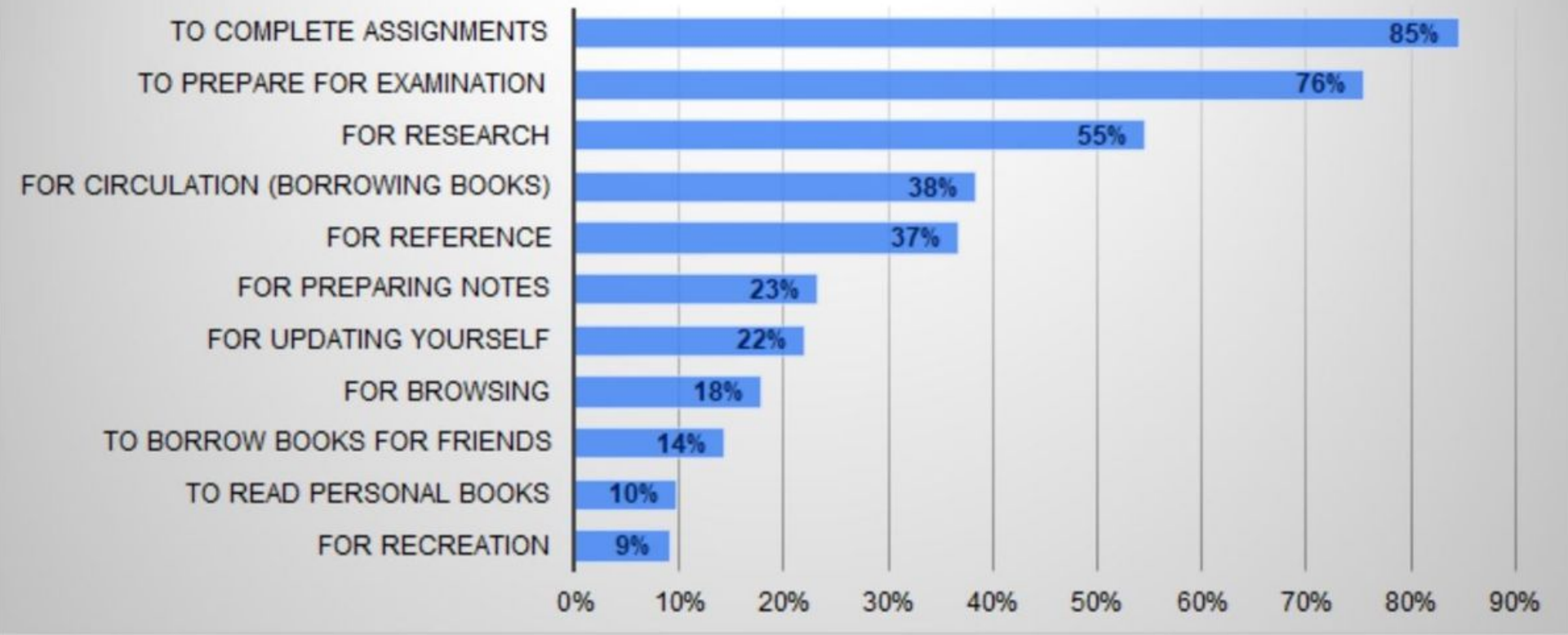

Figure 11

Purpose of students' visiting WIUT library during studies (Out of 607) 


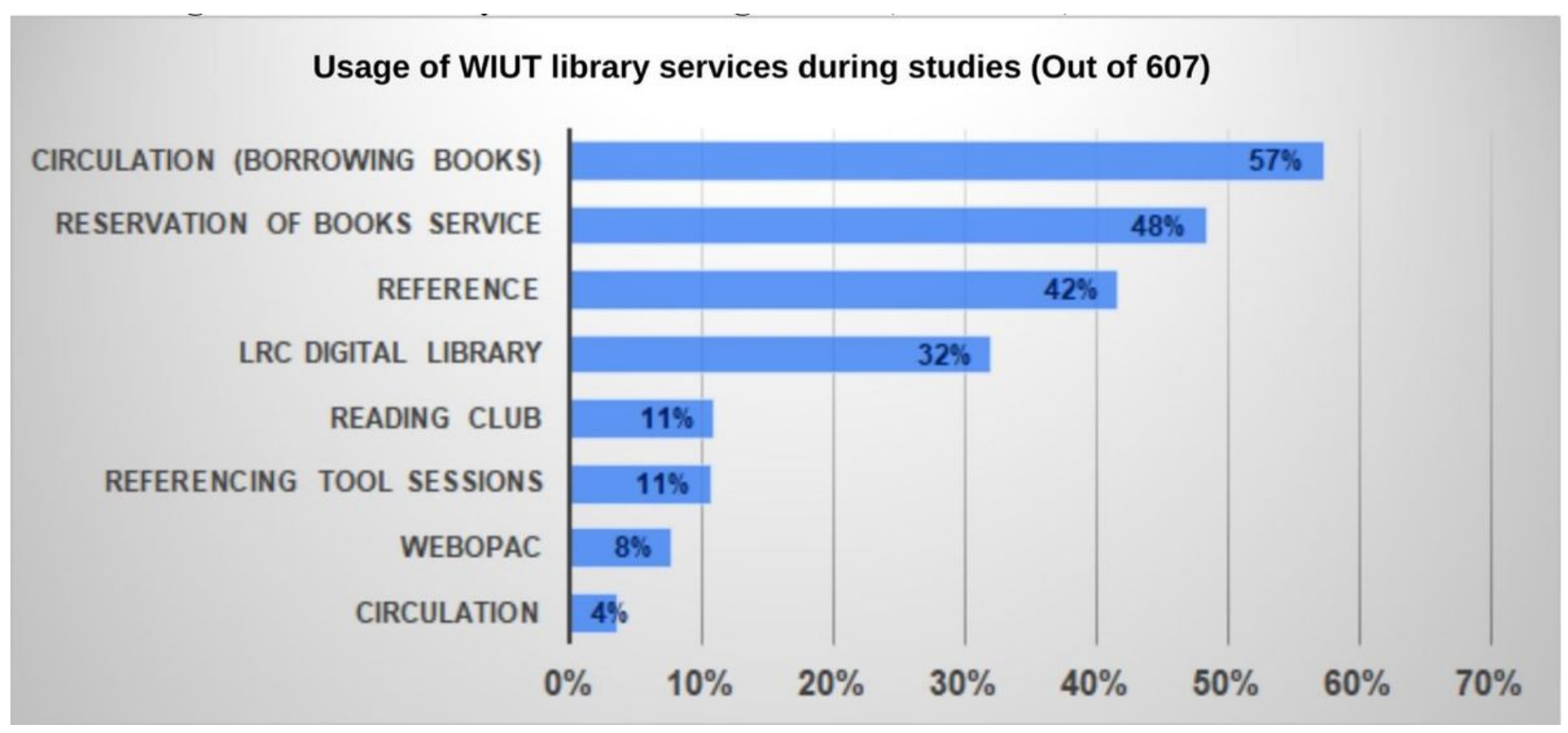

Figure 12

Usage of WIUT library services during studies (Out of 607)

\section{Supplementary Files}

This is a list of supplementary files associated with this preprint. Click to download.

- Appendices.pdf 